\title{
Autumn Quarterly Meeting, 1981
}

The Autumn Quarterly Meeting - a joint meeting with the Danish Psychiatric Society-was held at the Institute of Psychiatry and King's College Hospital Dental School, London, on 19 and 20 November 1981, under the presidency of Professor Kenneth Rawnsley.

\section{Scientific Meetings}

The papers presented at the scientific meetings were as follows:

Thursday 19 November: Morning Session A

Different Countries, Cultures and Climates

The history of psychiatry in Denmark-Professor Niels Reisby

Homicide in Iceland-Dr Hannes Petursson and Mr G. Gudjonsson

Psychiatry in Greenland-Dr Inge Lynge

A cultural perspective on hysteria-Dr Julian Leff

Repeated prevalence investigations of the population of Samsфe-Dr Jørgen Achton Nielsen

The mental health of Pakistanis in England-Raymond Cochrane, PhD

Mania and relative humidity-Dr David Mawson

Morning Session B

Mothers and Babies

Mood changes in the puerperium-Professor R. E. Kendell

What are the puerperal neuroses?-Dr John L. Cox

Maternity blues in East African mothers-Dr Brian Harris

Patterns in communication with the 0-3 months old infantDr Lene Lier

What is the significance of the early mother-baby relationship?-Kay Robson, PhD

Crying and non-crying babies-Dr D. Vorster

Techniques in interviewing parents-Dr A. D. Cox

Morning Session C

Models of Interiention in Groups

The position of psychotherapy in Danish psychiatry-Dr Ebbe Linnemann

Action techniques in groups-Dr Mark Aveline

Directive group methods-Mrs Elizabeth Mitchell

Family groups: The role of the therapist-Dr Alan Cooklin

Thursday 19 November: Afternoon Session A

Affective Disorders I: Lithium

Morbidity and toxicity in a three-year trial of lithium, amitriptyline and placebo in unipolar depressive illness-Dr A. I. M. Glen

Is flupenthixol a prophylactic alternative to lithium?Professor Mogens Schou

The relationship between plasma lithium concentration and its clinical and biological effects-Dr R. P. Hullin, FRIC

Side effects of long-term lithium treatment: Findings and implications-Dr Per Vestergaard

Lithium following ECT: Therapeutic benefits and sideeffects-Dr M. T. Abou-Saleh

Affective Disorders II: Methodological Issues

Rating scales-Dr Per Bech

Bimodality and the nature of depression-Dr Brian Everitt

\section{Afternoon Session B}

Childhood and After

Lead levels, intelligence and attainment in schoolchildrenDr W. Yule

Are there hyperactive children in Europe?-Dr Eric Taylor

Characteristics of the younger patients with anorexia nervosa: Preliminary report-Professor Kai Tolstrup and Dr Torben Isager

Personality and Neurotic Disorders

Borderline states during adolescence-Dr Tove Aarkrog

A ten-year study of abnormal personality-Professor H. J. Walton

High discrepancy between self-perceived real and ideal self: Interactions between self-regulation and neurotic disorders-Michael H. Bruch, Dip. Psych and J. Stechow. Dip. Psych

\section{Afternoon Session C}

Training in Behaviour Therapy

Conception. planning and content of the AUTP course-Dr Michael Crowe

A survey of the cases treated-Dr Anthony Purches

The teaching content of the course-Dr S. K. Singh

Practical difficulties for trainees-Dr H. N. Ghadiali

Teaching trainees at one's own hospital-Dr Margaret Beedie

Role play of typical case presentation-Drs Joseph Connolly, C. Chacon, Hemlata Ghadiali and Bashur Ghose

Friday 20 November: Morning Session A

Biological Approaches to Affective Disorders

Investigations in twins in relation to manic-depressivity-Dr Aksel Bertelsen

Antidepressants and atypical depression-Professor E. S. Paykel

Affective disorders: New and old treatments-Professor Ole Jørgen Rafaelsen

Stress, depression and adrenoceptors-Dr Iain Campbell

Alpha-adrenoceptors and depressive illness-K. M. Wood, $\mathrm{PhD}$ 
Morning Session B

The Political Abuse of Psychiatry

The College and the political abuse of psychiatry-Dr Peter Sainsbury

Abuse of psychiatry in the Soviet Union: Political aspects of the current situation-Peter Reddaway, MA

Psychiatrists and dissidents in the USSR-Mr Vladimir Bukovsky

Protection of the mentally ill-Dr Hans Adserballe

Morning Session C

Joint Meeting of the British Society of Gastro-Enterology and the Royal College of Psychiatrists' Dependencel Addiction Group

A comparison of laboratory and questionnaire screening tests for alcoholism-Dr M. Bernadt

The role of the physicians in recognizing alcoholism-Dr Peter Hunt

Alcohol problems on the medical ward-Dr Mark Rake

A two-year follow-up of police referrals to the Manchester Detoxification Centre-Dr J. D. Makanjuola

The physician in industry-Dr Robin Walker

The physician and female alcoholics-Dr Marsha Morgan

Is medical education on alcoholism effective?-Mr Marcus Grant

Friday 20 November: Afternoon Session A

Drugs and Their Side Effects

On and off with benzodiazepines-Professor Ian Oswald

Effects of long-term drug administration in psychiatric patients-Dr Philip Thomas

Weekly pimozide as maintenance therapy in chronic schizophrenia-Dr Robin G. McCreadie

Afternoon Session B

Schizophrenia

Biological research in schizophrenia with special reference to amines GABA and endorphines-Dr Rasmus Fog

CT-scans in schizophrenic and normal twins: $l$. Ventricular brain ratio-Dr Adrianne Reveley

CT-scans in schizophrenic and normal twins: II. Cerebral asymmetry-Dr Michael Reveley

Positron emission tomography in schizophrenics and controls-Dr Graham Shepherd

Afternoon Session C

Community Psychiatry

Measurement of rehabilitation progress-Dr J. W. Affleck

Problems amongst families of the victims of severe brain injury-Professor Michael Bond

Latent psychopathology of chronic epileptics living in the community-Dr J. Kogeorgos

Maudsley Lecture

On Friday 20 November, SIR JoHN WOOD, Faculty of

Law, University of Sheffield, delivered the Maudsley Lecture, 'The Impact of the Modes of Thought of Lawyers on the Practice of Psychiatry'. The Vote of Thanks was proposed by Dr P. G. McGrath.

\section{Business MEeting}

The Business Meeting was held on Friday 20 November 1981.

\section{Minutes}

The Minutes of the previous meeting held on 29 April at Sunnyside Royal Hospital, Montrose (Bulletin (1981), 5, 192-94) were approved and signed as a correct record.

\section{Obituary}

The PRESIDENT announced with regret the death of the following members:

Edward William Anderson, retired Professor of Psychiatry, University of Manchester.

Gladys Beryl Beinart, Clinical Assistant, Midland Nerve Hospital, Edgbaston, Birmingham.

John BOWER, Executive Director, The Tranquille School, Tranquille, British Columbia, Canada.

Conor Michael Brennan, Medical Director, Calderstones Hospital, Whalley, Blackburn, Lancashire.

Murari Chandra, Consultant, Department of Psychiatry, Queen's Park Hospital, Blackburn, Lancashire.

IsAaC Irost, Consultant, Merseyside Regional Health Authority.

JoHN KLAUBER, formerly Consultant, London Clinic of Psycho-Analysis.

Charles Follen McKim Maloney, Consultant, State Hospital. Carstairs, Scotland.

Eric William Shepherd, retired Consultant Psychiatrist, Leavesden Hospital, Abbots Langley, Watford, Herts.

\section{Registrar's Report}

On behalf of Professor Timbury, who apologized for his unavoidable absence. the PREsident presented the Registrar's report:

- Council met on 23 October and the Court of Electors on 12 October: there have been four meetings of the Executive and I inance Committee since my last Report.

- Dr Joze Jancar was elected by Council to be VicePresident for a period of two years.

- College proposals for Mental Health Commissions have been widely discussed and have in general received a favourable response. The Mental Health Amendment Bill was published last week and was received by the Executive and linance Committee on 13 November. The President. Registrar and Chairman of the Special Committee which prepared our earlier comments are drafting a preliminary response based on our previously published statements. A Niorking Party of the Public Policy Committee will prepare a more detailed response which it is hoped will be submitted to Council in January. Any member of the College who 
wishes to do so is invited to send comments to the Registrar.

-The annual informal meeting with members of the DHSS was held on $25 \mathrm{July,}$ and a number of matters of mutual concern were discussed, including mental health legislation, the Nodder Report. the issue of written guidelines for detained patients and a review of the progress with Regional Secure Units.

'Council received the Report of the ECT Research Project. which has now been published and was the subject of a press conference earlier this week. Council has set up a small Special Committee, under the chairmanship of the President. to prepare a formal response to the results and recommendations of the Report, and this Committee's suggestions will be discussed at the next Council meeting in January 1982.

The Education Committee and Council have commended a report prepared by the Association of University Teachers of Psychiatry on 'Sciences Basic to Psychiatry', and it is hoped that this report will be published in the Bulletin soon to assist candidates for the Membership and their teachers.

'A new application form for recognition by the College as a Psychiatric Tutor has also been introduced by the Education Committee.

'Council noted that Dr Ashley Robin had retired as Chairman of the Manpower Committee and has been replaced by Fiona Caldicott. The College is extremely grateful to $\mathrm{Dr}$ Robin for his considerable help with manpower matters.

'The Court of Electors has approved the appointment of a number of new Regional Advisers and the appointment of 'Deputy Regional Advisers.

'A small Working Party has been set up by the Court to consider the future of the MRCPsych Examination. No immediate changes are anticipated, but the form and content of the Preliminary Test may eventually be changed. One hundred and sixty-five candidate's passed the last sitting of the Preliminary Test - a pass rate of 49 per cent. A further 69 Inceptors were admitted to the College.

'The Public Policy Committee has set up a Working Party to review the work of the Lord Chancellor's Visitors and another to prepare guidelines on the management of cases of attempted suicide. Comments on the recent Green Paper entitled 'Care in the Community' have been sent to the DHSS.

'The Nursing Committee of the College are arranging a one-day symposium on nursing matters in association with the Spring Quarterly Meeting which will be held in Liverpool from 19 to 21 April, 1982.

-The College is extremely grateful to Dr Birley and his colleagues at the Institute of Psychiatry for the arrangements for this Quarterly Meeting.'

\section{Resolution}

DR Peter Sainsbury introduced the following
Resolution which he had seconded. The proposer, $D_{R}$ SIDNEY BLOCH, was prevented by urgent family matters from attending.

'It is resolved that the Royal College of Psychiatrists requests that the General Assembly of the World Psychiatric Associa tion at its meeting in Vienna in 1983 considers the following resolution:

"In view of (a) well documented evidence of the continuing systematic abuse of psychiatry for political purposes in the Soviet Union since the General Assembly's resolution of September 1977 to "renounce and expunge these practices" and (b) the failure of the All-Union Society of Neurologists and Psychiatrists to co-operate at all with the WPA's Review Committee on Political Abuse of Psychiatry in its investigation of various complaints by the Royal College of Psychiatrists and other WPA member societies.

this General Assembly resolves that the All-Union Society should now be expelled from the WPA until such time as the All-Union Society can show that the political abuse of psychiatry has been brought to an end."

Dr Sainsbury said that the Resolution continued the lead that the College had always taken in condemning the political abuse of psychiatry and that it should be passed now to allow the Soviet Union plenty of time to respond to the World Psychiatric Association's investigations before the Congress in Vienna in 1983.

Members participating in a wide-ranging discussion included Dr M. O'Shea, Dr P. Brook, Dr Dale Beckett, Professor I. Oswald, Dr M. Teush, Dr R. Reeves, Dr J. Fisk, Dr G. Low-Beer, Dr S. Levine, Dr J. MacKeith and Dr P. Bebbington. It was generally felt that any imperfections in the British NHS, particularly in relation to detained patients, should not be allowed to cloud the issue of abuse of psychiatry in the Soviet Union or to prevent the College giving its support to Soviet psychiatrists and others who were helping detainees, including the many whose cases were not publicized.

An Amendment to suspend the All-Union Society rather than expel it from the WPA (proposed by Dr Dale Beckett and seconded by Professor (an Oswald) was defeated, and the original Resolution was passed by a large majority.

\section{Announcements}

Dr AAkrog, President of the Danish Psychiatric Society, expressed gratitude to the President and members of the College for the hospitality the Danish Psychiatric Society had received during the Quarterly Meeting.

\section{Social Events}

The President and his wife were 'At Home' at the College on Thursday 19 November to celebrate the tenth anniversary of the College - over 200 members and visitors were able to attend. 